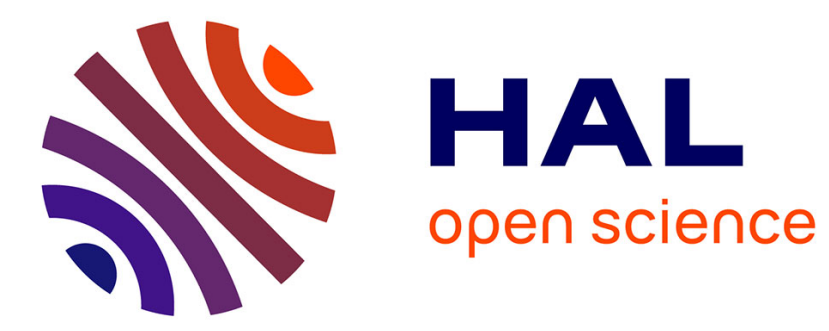

\title{
Changes in weed species composition in irrigated agriculture in Saharan Algeria
}

Amar Eddoud, Elise Buisson, L. Achour, K. Guediri, S Bissati, H Abdelkrim

\section{To cite this version:}

Amar Eddoud, Elise Buisson, L. Achour, K. Guediri, S Bissati, et al.. Changes in weed species composition in irrigated agriculture in Saharan Algeria. Weed Research, 2018, 58 (6), pp.424-436. 10.1111/wre.12328 . hal-01929114

\section{HAL Id: hal-01929114 https://hal.science/hal-01929114}

Submitted on 21 Nov 2018

HAL is a multi-disciplinary open access archive for the deposit and dissemination of scientific research documents, whether they are published or not. The documents may come from teaching and research institutions in France or abroad, or from public or private research centers.
L'archive ouverte pluridisciplinaire HAL, est destinée au dépôt et à la diffusion de documents scientifiques de niveau recherche, publiés ou non, émanant des établissements d'enseignement et de recherche français ou étrangers, des laboratoires publics ou privés. 
1 Changes in weed species composition in irrigated agriculture in Saharan Algeria 2

3 A EDDOUD*, E BUISSON $\dagger$ L ACHOUR,+ K GUEDIRI $\$$, S BISSATI $\$ \&$ H ABDELKRIM $4 x$

6 * Université Kasdi Merbah Ouargla, Laboratoire de Bio-Ressources Sahariennes :

7 Préservation et Valorisation, Faculté des Sciences de la nature et de la vie et des sciences de 8 la terre et de l'univers, Ouargla 30000 Algeria, $\dagger$ Institut Méditerranéen de Biodiversité et 9 d'Ecologie (IMBE), Université d'Avignon et des Pays de Vaucluse, UMR CNRS IRD Aix 10 Marseille Université, IUT Agroparc, BP 61207, 84911 Avignon cedex 09, France, † 11 Université Kasdi Merbah Ouargla, Département des sciences agronomiques Faculté des

12 Sciences de la nature et de la vie et des sciences de la terre et de l'univers, Ouargla 30000

13 Algeria and ${ }^{\chi}$ Ecole Nationale Supérieure d'Agronomie, Département Botanique El14 Harrach, Alger 16200 Algeria

Running head: Changes in weed composition in Saharan Algeria

22 Correspondance: Dr Elise Buisson, Institut Méditerranéen de Biodiversité et d'Ecologie (IMBE), Université d'Avignon et des Pays de Vaucluse, UMR CNRS IRD Aix Marseille Université, IUT site Agroparc, BP 61207, 84911 Avignon cedex 09, France. Tel: (+33) 490843858; Fax: (+33) 490843807; E-mail: elise.buisson@ univ-avignon.fr,

26 elise.buisson@imbe.fr 
31 This work characterizes the changes in composition of the weed flora commonly associated with certain southeastern Algerian crops over a twenty-year period. Vegetation sampling was carried out between 1990 and 2010 in three one-hectare date palm plantations that do not

34 have understory crops, six 400- $\mathrm{m}^{2}$ greenhouses used for market gardening, and three 30-ha cereal center-pivot irrigation plots. In total, 162 species belonging to 40 families were recorded. As in many other agroecosystems around the world, the dominant families are Poaceae, Asteraceae, Brassicaceae and Amaranthaceae representing 45.1\% of the species identified. The weed communities were characterized by a set of species from various origins: species with biregional, triregional, and multiregional origins, Saharo-Arabian and Mediterranean species were particularly well represented. Overall, the most common weed species were: Chenopodium murale, Lolium multiflorum, Melilotus indicus, Lysimachia arvensis, Sonchus oleraceus, Setaria verticillata, Polypogon monspeliensis and Erigeron canadensis, all of which are therophytes. The weed flora differed among the three sampled agroecosystems, which is to be expected, as their respective management sequences are quite different. Weed monitoring over the 20 years showed that weed composition changed overtime, particularly in the palm plantations and the cereal plots. For a better understanding of the drivers of weed composition and changes over time and better weed management, studying weed provenance (crop seed purchase, and organic fertilization) as well as agricultural practices is necessary.

Keywords: agroecosystems, camel rangeland, cereal center-pivot irrigation plots, date palm plantations, greenhouses, market gardening 
Global changes influence weed distribution, species dominance, and other aspects of weed communities in agroecosystems (e.g. climate change: Zicka and Dukes, 2011). Changes in agricultural practices associated with intensified crop production are by far the leading root cause of weed dynamics: this follows directly from the ecological implications of increased seeding and planting, increased fertilizer and pesticide use, and simplified crop rotation (Kleijn et al., 2009). On the one hand, the difficulty in controlling weeds is one of the major reasons for which farmers are forced to relinquish cultivated plots and to plow new ones; on the other hand, some weed control practices have proven detrimental to many of the plant and animal communities that are associated with agricultural environments (Flohre et al., 2011) while weeds can play an important role in supporting diversity for higher trophic levels (Marshall et al., 2003). Whereas these changes occur on weed communities, a thorough knowledge of the composition of weeds, along with their spatial and temporal distribution, is a prerequisite for good weed management in agroecosystems.

In Algeria, several studies have increased our understanding of the composition and distribution of weed flora in various northern regions of the country, with a Mediterranean climate, such as: on the Mediterranean central coast (Chevassut et al., 1988; Boulfekhar, 1989; Fenni, 1991; Abdelkrim, 1995), and on the Mediterranean north-eastern Algeria (Fenni, 1991) and north-western Algeria (Kazi Tani et al., 2012) coast. However, many agricultural regions of the country remain under-characterized.

Indeed, there currently exist no studies on the weed flora of the Saharan Algeria. Algeria has a flora comprising about 3139 species, of which 653 species (accounting for $12.6 \%$ of the total number of species) are endemic and distributed among nearly 150 families. Among the endemic flora, more than $25 \%$ of the species are associated with crops (Quézel \& Santa, 1962-1963). Botanical and plant ecology studies in the Sahara regions are scarce and mainly oriented towards the native flora of natural areas, such as that of camel rangelands (Ozenda, 2004; Chehma et al., 2008) and conservation and narrow endemic species (Brito et al., 2013; Migliore et al., 2013).

Our present work aims to show whether the composition of the weed flora associated with irrigated crops in southeastern Saharan Algeria has changed over a period of twenty years from 1990 to 2010 . We studied a set of cereal fields, greenhouses and palm plantations. We hypothesized that the weed flora of cereal fields and palm plantations would change little 
interventions are relatively minor in palm plantations after their establishment. We expected more changes in greenhouses where practices potentially evolve more rapidly.

\section{Materials and Methods}

\section{Study area}

The study was conducted in Hassi Benabdellah, located in northeastern part of Saharan Algeria, about $800 \mathrm{~km}$ from Algiers (32 $01^{\prime} \mathrm{N}$; 5²8'E; Fig. 1). The northern Sahara, which covers an area of 1 million $\mathrm{km}^{2}$, receives precipitation in the winter and yields $100 \pm 50 \mathrm{~mm}$ of rainfall per year (Hamdi-Aissa et al., 2004). It is essentially a transition zone between the northern African Mediterranean steppes and the central Sahara desert, and it was selected mainly for its agricultural potential. Indeed, many important crops, such as dates, greenhouse gardens, and cereals grown using center-pivot irrigation (sometimes called central pivot irrigation or circle irrigation), are all farmed in this region. A relatively recent import to the area, intensive crop cultivation, first appeared in the region in the late 1960s and early 1970s, mainly occupying what had once been open camel rangeland. Although irrigation is applied all year long in the date palm plantations (surface irrigation; once a week from November to March and 2 to 3 times a week the rest of the year), it is only applied during the growing season on cereal plots (center pivot irrigation; $866 \mathrm{~mm} / \mathrm{m}^{2}$ ) and market gardening greenhouses (surface irrigation; twice a week from November to February and 3 times a week from March to May). None of the plots selected for this study were treated with herbicides.

\section{Sampling method}

The present study covers the twenty-year period beginning in 1990, and handles the full twenty years in two stages. The first stage relies on a synthesis of all the data from previous studies mentioning exhaustive weed flora sampling in the ITCMI (Institut Technique des Cultures Maraichères et Industrielles) and ITDAS (Institut Technique de Développement de l'Agriculture Saharienne) research stations between 1990 and 2002. For that period, one presence-absence plant list was compiled per year surveyed per crop type (Table 1; ITCMI \& ITDAS, 2002). The second stage of the analysis, covering the period from October 2003 to June 2010, is based on weed surveys conducted by the authors according to the following protocol. For both stages, to match the seasonal planting and harvest schedule, surveys were carried out starting in October of each year (x), and repeated in February and June of the following year $(x+1)$, to give a total of three surveys per year. The data from each set of three surveys were then taken together to fully characterize each October $x$ to June $x+1$ crop 
122 year. We used the Base de données des plantes d'Afrique for plant nomenclature (CJB \& 123 SANBI, 2014). The botanical attributions for weed species are listed in Appendix 1 in

124 Supplementary Material.

126 Sampling in cereal plots

127 Three 30-ha cereal center-pivot irrigation plots, hereafter referred to as cereal plots, cultivated 128 with either hard (Triticum turgidum L. subsp. durum (Desf.) Husn.) or soft (Triticum aestivum L. subsp. aestivum) wheat, were selected. These plots started to be cultivated in the mid 1980's. In each cereal plot, three 100m-long and 2m-wide transects were randomly placed and sampled by establishing a presence-absence plant list three times per year between wheat seeding and harvesting. The three samples taken on the same transect year were pooled for analysis $(n=63 ; 6$ sites $\times 3$ transects $\times 7$ years). The pre-2003 data, collected over 8 years, were considered together with the post-2003 data in the multivariate analyses (with $n=$ $63+8=71)$.

\section{Sampling in market gardening greenhouses}

138 Six 400-m² greenhouses, cultivated since the early 1980's, were selected. In each greenhouse,

139 three 50m-long and $1 \mathrm{~m}$-wide transects were randomly placed and sampled by establishing a

140 presence-absence plant list three times per year, although the exact time of year at which 141 sampling occurred varied according to crop type (and therefore crop cycle). The three 142 samples taken within the transect year were pooled for analysis $(n=126 ; 6$ sites $\times 3$ transects $143 \times 7$ years). The pre-2003 data, which came from for 13 years (Table 1), were considered 144 together with the post-2003 data in the multivariate analyses (with $n=126+13=139$ ).

\section{Sampling in date palm plantations}

147 For the palm cultivation portion of the study, three one-hectare date palm (Phoenix 148 dactylifera L.) plantations without understory crops were selected. These plantations had 149 been established in 1972. In each plantation, three 100m-long and 10m-wide parallel 150 transects were randomly placed and sampled by establishing a presence-absence plant list three times per year. The three samples taken on the same transect from October in the year $\mathrm{x}$ to June in the year $\mathrm{x}+1$ were pooled for analysis. This means that a given crop year was

153 statistically characterized by a total of 3 sites $\times 3$ transects $\times 7$ years, $n=63$ ). The pre-2003

154 samples consist of data collected over 9 years (Table 1), and are considered in the 
multivariate analyses (with $n=72$, following from $9+63=72$ ) in which the pre-2003 and post-2003 datasets are handled together.

Plant species study

159 In order to analyze the characteristics of the species found on the various plots, all species 160 were classified according to (1) their family; (2) their chorotype and (3) their life-form according to Raunkiaer's life form using the following floras: Quézel \& Santa (1962-1963),

162 Ozenda (2004), Tison \& de Foucault (2014) and Danin (2015) (see Appendix 1 in

163 Supplementary Material). The chorotypes were simplified in 7 categories: 1 . Alien species from Americas, Australia and South Africa, 2. A complex chorotype containing species with biregional, triregional, and multiregional origins, 3. Euro-Siberian (ES), 4. Irano-Turanian stricto sensu (IT), 5. Mediterranean stricto sensu (M), 6. Saharo-Arabian stricto sensu (SA), and 7. Sudanian (S).

\section{Data analysis}

170 We analyzed differences in percentages of weed species / transect for each crop type separately, depending on the explanatory variable "chorotypes" (or "life forms)' using generalized linear models with binomial error distribution. When the explanatory variable was significant, we conducted pairwise comparisons with Tukey's pairwise comparison tests using function 'glht' in the package "multcomp" in R (R Core Team 2018). For all tests, Pvalues lower than 0.05 were considered as statistically significant.

We analyzed differences in number of weed species / transect along time for each crop types separately. Two Mixed-effects Generalized Linear Models were compared for each crop type: one with "years" as an explanatory variable and one without. For these analyses, only the data from 2003 to 2010 were used. If the first model had a lower AIC

180 (Akaike Information Criterion), time was considered as having a significant effect and we conducted pairwise comparisons with Tukey's pairwise comparison tests using function 'glht' in the package "multcomp" in R (R Core Team 2018). The same procedure was carried out to assess the differences in percentages of weed species / transect along time for particular chorotypes or life forms, considering crop types separately.

The relationships between explanatory variables (crop types or years) and weed assemblages were explored using Correspondence Analyses (CA). To describe the vegetation corresponding to each crop type, a first CA was run on all vegetation surveys ( 282 samples $\times$ 
189 CAs were run 1) on the palm plantation samples (72 points $\times 123$ species), 2) on the cereal 190 plot samples $(71$ points $\times 110$ species $)$ and 3$)$ on the greenhouse samples $(139$ points $\times 32$ species). These analyses were followed by a Multiple Response Permutation Procedure analysis (MRPP) to determine the statistical significance between the crop types or the years.

193 On the figures, for clarity, only the species the most correlated to axes 1 and 2 are shown. All 194 of the analyses were conducted with R 3.4.4 (R Core Team 2018), univariate analyses with its 195 package "Ime4" and "multcomp" and multivariate analyses with its packages "ade4" and "vegan".

\section{Results}

Weed composition depending on crop types

200 The number of weed species varied from 119 species in the palm plantations $\left(9000 \mathrm{~m}^{2}\right.$ explored every year) to 104 in cereal plots $\left(1800 \mathrm{~m}^{2}\right.$ explored every year) and 31 species in greenhouses (900 $\mathrm{m}^{2}$ explored every year). In total, during the two sampling periods (19902002 and 2003-2010), we identified 162 weed species from 40 botanical families, three of which made up for almost half of the species in the study (45.1\% of the species): Poaceae (20.4\%), Asteraceae (14.2\%) and Brassicaceae (10.5\%) of the species. Poaceae (19.2\%, $35.5 \%$ and $22.7 \%$ of the weed species in cereal plots, greenhouses and palm plantation respectively), Asteraceae $(18.7 \%, 16.1 \%, 14.3 \%)$ were the dominant families in all crop types. The third most represented family was Brassicaceae in cereal plots $(14.4 \%$ of the species). In greenhouses and palm plantations Amaranthaceae was the third most represented family (12.9\% and 7.6\% respectively) (see Appendix 1 in Supplementary Material). weed species composition between the crop types (observed delta: 0.37; expected delta: 0.60; p-value $<0.001)$. The first two first axes of the CA explained $31.0 \%$ of the total inertia. As shown in Fig. 4, axis 1 (16.4\%) delineated cereal plot samples correlated with Anisantha madritensis, Avena barbata, Daucus carota, Emex spinosa, Fagonia glutinosa, Launaea capitata, Raphanus raphanistrum, Sinapis arvensis, and Trigonella polycerata, from greenhouse samples correlated with Amaranthus retroflexus, Convolvulus arvensis, Cynodon dactylon, Cyperus rotundus, Digitaria nodosa and Senecio vulgaris (Fig. 4; the botanical attributions for weed species are listed in Appendix 1 in Supplementary Material). Axis 2 $(14.6 \%)$ separated these samples from the palm tree plantation samples correlated with Cressa cretica, Tamarix gallica, Juncus maritimus, Euphorbia chamaecyse, Sonchus maritimus, and Phragmites australis (Fig. 2). 
Weed chorotypes and life-forms depending on crop types

The study area, located in the northeastern part of Saharan Algeria, was characterized by a set of species from various origins. Overall, $47 \%$ of the species belong to the complex chorotype, $25 \%$ are Saharo-Arabian species and 18\% are Mediterranean species. The other categories (Alien, Euro-Siberian, Irano-Turanian, Saharo-Arabian and Sudanian) accounted for $10 \%$ of the species. The most common weed species on the three crop types were: Chenopodium murale, Lolium multiflorum, Melilotus indicus, Lysimachia arvensis, Sonchus oleraceus, Setaria verticillata, Polypogon monspeliensis and Erigeron canadensis, all of which are therophytes. Five of them belong to the complex chorotype (Chenopodium murale, Lysimachia arvensis, Polypogon monspeliensis, Setaria verticillata, Sonchus oleraceus), two are Mediterranean (Lolium multiflorum, Melilotus indicus), and one is an alien species from America (Erigeron canadensis).

In all three crop types, the most common chorotype category was the complex chorotype (Fig. 3). The second most common chorotype category in the cereal plots was Mediterranean (e.g. Lolium multiflorum, Avena barbata, Melilotus indicus, Sinapis arvensis), while it was Aliens (e.g. Erigeron canadensis, Cyperus rotundus) in the greenhouses and Saharo-Arabian (e.g. Moltkiopsis ciliate, Ifloga spicata, Launaea capitate, Tetraena alba) in the palm plantations (Fig. 3).

Overall, 'therophytes' was the most represented life-form (Fig. 4). Palm plantations were the crop type with the greatest diversity of life-forms, including perennials and a significant amount of hemicrytophytes (Fig. 4; Appendix 1 in Supplementary Material). Few species were geophytes and perennials, mainly found in the palm plantation. More than $60 \%$ of the species exhibiting a Mediterranean range or belonging to our complex chorotype category were therophytes. This life-form represented less than $50 \%$ of the species with a Saharo-Arabian range, while other species with this origin mainly belonged to chamaephytes or hemicryptophytes (only one geophyte: Euphorbia guyoniana).

Weed species richness changes with time

253 The number of weed species in cereal plots tended to decrease from 1990 to 2003 and then significantly increased from 2003 to 2010 (df=6, F=22.01, p-value<0.001). In greenhouses,

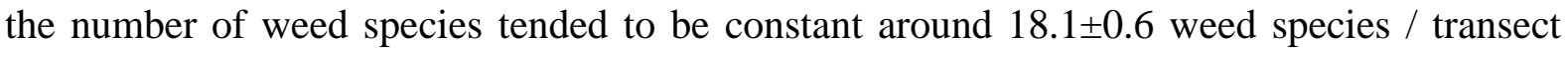
from 1990 to 2010, with a few punctual increases (e.g. in 2004-05: 22.4 $\pm 1.2 ; \mathrm{df}=6, \mathrm{~F}=5.21$, 
p-value<0.001). The number of weed species in palm plantations tended to increase from 1990 to 2003 and then stabilized around 52.3 \pm 3.0 weed species / transect $(\mathrm{df}=6, \mathrm{~F}=1.42$, pvalue $=0.224)$ (Fig. 5).

Weed chorotypes and life-forms changes with time

262 Significant variations of percentages of therophytes were observed in the greenhouses, with no specific trends (Table 2). Variations of percentages of therophytes in the cereals plots and of therophytes and hemicryptophytes in the palm plantations were not significant.

Significant variations of percentages of species in the complex chorotype category were observed in the cereal plots and in greenhouses, with no specific trends (Table 2; Fig. 6). Percentages of alien species significantly increased in the greenhouses, while percentages of Saharo-Arabian species decreased in the palm plantations (Table 2; Fig. 6).

\section{Weed composition changes with time}

The CA, as run on cereal plot data, showed a clear change in species composition with time and this was confirmed by the MRPP analysis showing a significant difference between the dates (observed delta: 0.17; expected delta: 0.37; p-value<0.001); the first two first axes of the CA were found to explain $37.6 \%$ of the total inertia. As shown in Fig. 7, axis 1 (23.9\%) delineated old samples (1990-2000) correlated with Ammosperma cinereum, Atractylis delicatula, Brocchia cinerea, Diplotaxis acris, Launaea mucronata, Malcolmia africana and Paronychia arabica from other samples (Fig. 7). Axis 2 (13.7\%) separated the samples gathered between 2003 and 2005, correlated with Callipeltis cucullaris, Lysimachia arvensis and Rostraria cristata from the more recent samples (2008 to 2010) correlated with Calendula arvensis, Frankenia pulverulenta, Galium tricornutum, Henophyton deserti, Papaver rhoeas, Scandix pecten-veneris, Sonchus asper, Stipagrostis obtusa and Tetraena alba (Fig. 7).

The CA, as run on the greenhouse data, only showed that some years (1990-91, 2004-05, 2006-07) were different from others (Fig. 8) and this was confirmed by the MRPP analysis showing a significant difference between the dates (observed delta: 0.22; expected delta: 0.30; p-value<0.001); the first two first axes of the CA were found to explain $32.2 \%$ of the total inertia. Axis 1 (17.1\%) delineated the 2004-05 samples, correlated with Dactyloctenium aegyptium and Solanum nigrum, from the samples from other years. Axis 2 (15.1\%) distinguished the oldest samples (1990-1991) correlated with Cutandia dichotoma and Spergularia marina (Fig. 8). 
291 The CA, as run on the palm tree plantation data, also showed a clear change in species 292 composition with time and this was confirmed by the MRPP analysis showing a significant 293 difference between the dates (observed delta: 0.37; expected delta: 0.49; p-value<0.001); the 294 first two first axes of the CA (axis 1: $16.6 \%$ and axis 2: 11.3\%) explained $27.9 \%$ of the total 295 inertia. As shown in Fig. 9, Agathophora alopecuroides and Stipagrostis plumosa were mainly found in the early years, followed by Anethum graveolens and Echium pycnanthum at the end of the 1990's and by Glaucium corniculatum and Ogastemma pusillum the start of the $21^{\text {st }}$ century. Around the late 2000's, Cressa cretica, Cyperus rotundus, Phragmites australis Tamarix sp. became more common (Fig. 9).

300

\section{Discussion}

\section{Overall weed composition}

303 The three most common families encountered in this study, namely Poaceae, Brassicaceae and Asteraceae were such a dominating presence because they are important families of the Algerian flora, especially in the Sahara (Ozenda, 2004), and they are adapted to disturbed environments (Holm et al., 1977; Taleb \& Maillet, 1994). Indeed, Holm et al. (1977) report that Poaceae, Cyperaceae, Asteraceae, Polygonoceae, Amarantaceae, Brassicaceae and Fabaceae constitute the major crop weed families. Other studies in semi-arid Mediterranean and tropical environments have also shown that Amarantaceae, Asteraceae, Brassicaceae, Fabaceae, Poaceae, Polygonoceae, and Solanaceae are very common in the vegetation and seed bank (Dorado et al., 1999; Salama et al., 2016). Our results are also comparable to those reported by studies in Mediterranean Algeria (Boulfekhar, 1989), Morocco (Bouhache et al., 1994) and Egypt (Salama et al., 2016). The most common weed species recorded in this study (Chenopodium murale, Lolium multiflorum, Melilotus indicus, Lysimachia arvensis, Sonchus oleraceus, Setaria verticillata, Polypogon monspeliensis and Erigeron canadensis) are recognized as major weeds elsewhere in the world (e.g. USDA, NRCS 2015), with their status as invasive depending on the region considered. Chenopodium murale, Melilotus indicus, Sonchus oleraceus and Polypogon monspeliensis were also found to be dominant weed species in wheat, millet or alfa-alfa fields studied by Salama et al. (2016).

The proportion of weeds exhibiting Mediterranean or Saharan ranges was high, accounting for $43 \%$ of the species, but $47 \%$ of the weeds belong to our complex chorotype category, with biregional, triregional, and multiregional origins. According to Ozenda (2004), the flora of northern Sahara is characterized by a preponderance of the Saharan species with only some incursions of Mediterranean species. This apparent disparity between our 
observations and Ozenda's prediction can probably be explained by habitat differences. Ozenda described the flora of all Saharan habitats, including e.g. camel rangelands which experience recurrent disturbances due mainly to drought and grazing and which are thus characterized by an adapted Saharan flora. On the other hand our study was conducted in agroecosystems which are highly disturbed environments. Cultivated fields represent a particular kind of artificial ecosystem that is subject to tillage, pesticides, fertilizers, irrigation and other interventions, thus experiencing an exceptional frequency and intensity of disturbances intended to maintain favorable conditions for production (Smith, 1995). Artificial watering, in particular, provide conditions favorable to Mediterranean species

334 (Steinmaus \& Norris, 2002). These disturbances lead to a banalization of the weed flora (Kazi Tani et al., 2012) and a depletion of endemic species in this type of environment (Jauzein, 2001). With the Mediterranean and complex chorotype species being mainly therophytes (over 60\%), these provenances create a dominant therophytic component in the Saharan weed assemblage.

\section{Differences in weed composition between crop types}

341 The weed flora is mainly related to soil and climatic conditions, but also varies in composition and number of weed species depending on crop types and the agricultural practices associated with these crops (Zimdahl, 2013; Salama et al., 2016). These differences are explained by the differences in crop management sequence, particularly where it concerns tillage. In greenhouses, tillage occurs continuously throughout the growing season, as part of incorporating mineral fertilizers, weeding, and hoeing (to aerate the soil). In addition, greenhouse crops (Solanaceae, Cucurbitaceae, Fabaceae) offer more possibilities for rotation compared to the two other crop types, which are limited to a single botanical family (Poaceae in cereal plots and Arecaceae in palm plantations). Greenhouse crops therefore have a greater diversity of agricultural practices, and this can explain their relatively low number of weed species (Pyšek et al., 2005; Armengot et al., 2011). It can also explain the presence of Amaranthus retroflexus, Chenopodium murale and Senecio vulgaris, which have a very rapid life cycle. Ball (1992) also reports that in irrigated market gardening crops, tillage and crop rotation are the main factors explaining the floristic composition of weeds and the seed bank, which in turn explain the number of weed species of the vegetation in the plot.

In the cereal plots, tillage only occurs once a year at the time of crop establishment 
surroundings camel rangelands to colonize the cereal plots: e.g. Atractylis delicatula,

360 Carthamus eriocephalus, Ifloga spicata, and several species of Launaea. The cereal plots are characterized by a second group of weed species, of Mediterranean origin, probably sowed with wheat seeds (Tanji \& Taleb, 1997): e.g. Avena barbata, Daucus carota, Emex spinosa, Raphanus raphanistrum, Sinapis arvensis, and Trigonella polycerata.

In palm plantations without understory crops, tillage is limited to a single hydroagricultural development at the time of tree planting in which ditches are created to ensure irrigation of the date palms (Zaid, 2002). Once the plantation is established, the soil is not tilled anymore. Palm plantations are thus characterized by perennial species: chamaephytes (Cynodon dactylon), geophytes (Cyperus rotundus, Cressa cretica, Colchicum gramineum, Oxalis pes-caprae), hemicryptophytes (Phragmites australis, Erodium glaucophyllum, Juncus maritimus, Sonchus maritimus), and phanerophytes (Tamarix gallica). They are also characterized by weed species that prefer moist soil and can tolerate salt, such as Cressa cretica, Euphorbia chamaecyse, and Sonchus maritimus. Salt is a result of the high evaporation rate characterizing arid and semiarid climates, an effect that causes salt to accumulate in the top layer of the soil (Al-Amoud, 2010). It can also come from irrigation with marginal groundwater resources and from a rise in the water table (Bouarfa et al., 2009).

Changes in weed composition over time

In cereal plots, old samples are characterized by species found on the camel rangelands of the region, such as Ammosperma cinereum, Atractylis delicatula, Brocchia cinerea, Diplotaxis acris, Launaea mucronata, Malcolmia africana, Malva aegyptia and Paronychia arabica. With time, a mix of weeds (e.g. Sonchus asper) and segetal species (e.g. Papaver rhoeas, Galium tricornutum, and Scandix pecten-veneris) colonized these plots. These species are probably sown with the wheat seeds coming from the northern part of the country as has been shown to occur in Morocco (Tanji \& Taleb, 1997). While some species native to the camel rangelands progressively disappear from the cereal plots (Atractylis delicatula, Carduus getulus, Cornulaca monacantha, Paronychia arabica, and Sisymbrium reboudianum) others manage to maintain themselves (e.g. Henophyton deserti and Tetraena alba), although species of both groups belong to various life-forms (chamaephytes, hemicryptophytes and therophytes). On the other hand, a study run from 1985 to 2005 in southern Spain showed that weed diversity did not change over time (Hernandez Plaza et al., 2011). This might be explained by the fact that the fields had been cultivated with wheat for 10 years prior to the 
start of the study. This is unlike our own study, initiated just a few years after the start of cultivation in the mid 1980's. In order to better understand the drivers of change on the cereal plots, a thorough survey among farmers would need to investigate wheat seed provenances and changes in practices that might have gone unnoticed. A study of the species sown along with wheat seeds would also be useful, but might not to be feasible as one would need samples from seeds sown from 1990 to 2010. Finally, a seed bank study in cereal plots of various ages would provide information on native rangeland species depletion.

In the early years, indigenous species were already scarce in greenhouses which is probably due to the fact that these plots had been cultivated for 10 years before the start of the study. This crop type also induce the most disturbances of the three studied crop types. This and the frequent crop rotations (Solanaceae, Cucurbitaceae, Fabaceae) most probably explain the lack of patterns of weed communities through time. Indeed, the weed flora has not changed much in greenhouses over the last twenty years and is characterized by anthropophilous or widespread species (e.g., Amarantus retroflexus, Chenopodium murale, Erigeron canadensis, and Sonchus oleraceus) probably sown with crop seeds. Indeed, crop seeds are often bought from the northern part of the country and are not pure. Studying the species sown along with crop seeds would be useful to better understand weed species composition. A fertilization survey among farmers would also be helpful as they may have various kinds of practices, such as the use of chemical fertilizers, local organic fertilizers (ovine, caprine, mixed manure) or organic fertilizers from other parts of the country (ovine, caprine, bovine, mixed manure).

The vegetation of palm plantations formerly consisted of native species from local camel rangelands, such as Agathophora alopecuroides and Stipagrostis plumosa (Ozenda, 2004). Although the plantations were set in 1972, their establishment consisted of a single hydroagricultural development that disturbed the soil locally (Zaid, 2002): the disturbance was limited to a few square meters around each planted tree which were spaced $11 \mathrm{~m}$ apart. While palm tree plantations used to be well-drained, there is now a lack of maintenance of drainage systems, which combined with the water table rise, makes soils wetter. Also, the water from the water table is increasingly salty, and salt gradually accumulates in the soil over time (Bouarfa et al., 2009). Therefore, with time, weed flora characterizing humid and salty soils and consisting of such species as Cressa cretica, Cyperus rotundus and Phragmites australis, has colonized the area.

\section{Conclusions}


427 The weed flora after 20 years was very different among the three studied crop types, mainly 428 because their management sequences are different (Salama et al., 2016). Weed monitoring 429 over 20 years shows that weed composition is changing over time, particularly in cereal plots 430 and in palm plantations. Whereas changes are likely driven by lack of drainage maintenance 431 and salt accumulation in the case of palm plantations, more studies are needed to understand 432 weed species composition in the cereal plots and greenhouses. This first study on crop weed 433 composition in the Algerian Sahara is only a first step on the path to improved management, 434 and an analysis of weed provenance (e.g., crop seed types and use of organic fertilization) 435 and weed traits should be completed next.

436

\section{Acknowledgements}

438 We thank Mr Douadi Gousmi (Director of Benabdellah Experimental Station in Ouargla). 439 We also thank all the people who helped with our work, in particular Daniel Pavon (IMBE 440 botanist) who provided invaluable assistance in identifying plants and seedlings and who 441 helped us compiling plant information. We are grateful to the numerous dedicated reviewers 442 who helped to greatly improve the manuscript. 


\section{References}

ABDELKRIM H (1995) Contribution à la connaissance des groupements de mauvaises herbes des cultures du secteur algérois : Approche syntaxonomique et phénologique. Ph.D. thesis. Paris-Sud University, Paris, France.

Al-Amoud AI (2010) Subsurface drip irrigation for date palm trees to conserve water. Acta Horticulturae 882, 103-114.

Armengot L, José-María L, Blanco-Moreno JM, Romero-Puente A, Sans FX (2011) Landscape and land-use effects on weed flora in Mediterranean cereal fields. Agriculture, Ecosystems, Environment 142, 311-317.

BALL DA (1992) Weed seedbank response to tillage, herbicides, and crop rotation sequence. Weed Science 40, 654-659.

Bouarfa S, Marlet S, Douaoui A, et al. (2009) Salinity patterns in irrigation systems, a threat to be demystified, a constraint to be managed: Field evidence from Algeria and Tunisia. Irrigation and Drainage 58, S273-S284.

Bouhache M, Boulet C, Chougrani A (1994) Aspects floristico-agronomiques des mauvaises herbes de la région du Loukkos (Maroc). Weed Research 34, 119-126.

BOULFEKHAR N (1989) Etude phytosociologique de certains groupements de mauvaises herbes dans la plaine de la Mitidja, Algérie septentrionale. Thesis. Institut National Agronomique d'El Harrach, Alger, Algeria.

Brito JC, Godinho R, Martínez-Freiría F, Pleguezuelos JM, Rebelo H, Santos X et al. (2013) Unravelling biodiversity, evolution and threats to conservation in the SaharaSahel. Biological Reviews 89, 215-31.

Chehma A, FAye B, DJebar MR (2008) Productivité fourragère et capacité de charge des parcours camelins du Sahara septentrional Algérien. Sécheresse 19, 115-21.

Chevassut G, Abdelkrim H, Kiared Gh (1988) Contribution à l'étude des groupements de mauvaises herbes de la région d'el Harrach. Annales Institut National Agronomie El Harrach Alger 12, 690-702.

CJB \& SANBI (2014) Base de données des plantes d'Afrique - CJB Conservatoire et Jardin Botaniques de la Ville de Genève and SANBI South African National Biodiversity Institute, Pretoria, Available at http://www.ville-ge.ch/musinfo/bd/cjb/africa/ (last accessed 22 March 2018). 
DANIN A (2015) Flora of Israel Online. http://flora.org.il/en/plants/ (last accessed 22 March 2018).

Dorado J, Del Monte JP, LóPEZ-FANDo C (1999) Weed seedbank response to crop rotation and tillage in semiarid agroecosystems. Weed Science 47, 67-73.

FENNI M (1991) Contribution à l'étude des groupements messicoles des Hautes Plaines sétifiennes. Thesis. Sétif University, Sétif, Algeria.

Flohre A, Rudnick M, Traser G, Tscharntke T, Eggers T (2011) Does soil biota benefit from organic farming in complex vs. simple landscapes? Agriculture, Ecosystems, Environment 141, 210-214.

Hamdi-Aissa B, Valles V, Aventurier A, RibOlzi O (2004) Soils and brine geochemistry and mineralogy of hyperarid desert playa, Ouargla Basin, Algerian Sahara. Arid Land Research and Management 18, 103-126.

Hernandez Plaza E, Kozak M, Navarrete L, Gonzalez-Andujar JL (2011) Tillage system did not affect weed diversity in a 23-year experiment in Mediterranean dryland. Agriculture, Ecosystems, Environment 140, 102-105.

Holm LG, Plucknett DL, Pancho JV, Herberger JP (1977) The World's Worst Weeds: Distribution and Biology. Univ. Press of Hawaii, Honolulu.

ITCMI \& ITDAS (2002) Rapport d'activité de recherche de la station expérimentale de Hassi Ben AbdAllah-Ouargla pour la période allant de 1990 à 2002. ITCMI Institut Technique des Cultures Maraichères et Industrielles - ITDAS Institut Technique de Développement de l'Agriculture Saharienne.

JAUZEIN P (2001) Biodiversité des champs cultivés : l'enrichissement floristique. Dossier de l'environnement de l'INRA 21, 43-64.

KaZI TANi Ch, Le Bourgeois Th, Munoz F (2012) Aspects floristiques de la flore des champs du domaine phytogéographique oranais (Nord-Ouest algérien) et persistance d'espèces rares et endémiques. Flora Mediterranea 20, 5-22.

KLeiJn D, Kohler F, BALDi A, et al. (2009) On the relationship between farmland biodiversity and land-use intensity in Europe. Proceedings of the Royal Society B: Biological Sciences 276, 903-909.

Marshall EJP, Brown VK, Boatman ND, Lutman PJW, SQuire GR, Ward LK (2003) The role of weeds in supporting biological diversity within crop fields. Weed Research 43, 77-89. 
Migliore J, BAumel A, Juin M, et al. 2013. Surviving in mountain climate refugia: new insights from the genetic structure and diversity of the relict shrub Myrtus nivellei (Myrtaceae) in the Sahara desert. PLOS Biology 8(9): e73795.

OzEnda P (2004) Flore du Sahara, 3rd edition, Editions du Centre national de la recherche scientifique. Paris.

Pyšek P, JARošík V, KROPÁČ Z, ChYTRÝ M, WiLd J, TiChÝ L (2005) Effects of abiotic factors on species richness and cover in Central European weed communities. Agriculture, Ecosystems, Environment 109, 1-8.

QuEZEl P \& SANTA S (1962-1963) Nouvelle Flore de l'Algérie et des Régions Désertiques Méridionales, Tome 1 et 2. Editions du Centre national de la recherche scientifique. Paris.

R CORE TEAM (2018) R: A language and environment for statistical computing. R Foundation for Statistical Computing, Vienna, Austria. Available at: http://www.R-project.org/ (last accessed 22 March 2018).

SAlAma FM, El-Ghani MMA, El-TAYeh NA, Amro A, AbDrabbu H (2016) Weed flora of common crops in desert reclaimed arable lands of southern Egypt. Taeckholmia 36, 6285.

Smith CW (1995) Crop Production: Evolution, History, and Technology. John Wiley \& Sons Inc, USA.

STEINMAUS SJ \& NORRIS RF (2002) Growth analysis and canopy architecture of velvetleaf grown under light conditions representative of irrigated Mediterranean-type agroecosystems. Weed Science 50:42-53.

TAleb A \& Maillet J (1994) Mauvaises herbes des céréales de la Chaouia (Maroc) II. Aspect écologique. Weed Research 34, 353-360.

TANJi A \& TAleb A (1997) New weed species recently introduced into Morocco. Weed Research 37, 27-31.

Tison JM \& DE Foucault B (2014) Flora Gallica : Flore de France. Biotope Editions.

USDA, NRCS (2015) The PLANTS Database (http://plants.usda.gov, 22 July 2015). National Plant Data Team, Greensboro, NC 27401-4901 USA.

ZAID A (2002) Date palm cultivation. FAO Plant P. 156. Available at: http://www.fao.org/docrep/006/y4360e/y4360e00.HTM (last accessed 22 March 2018).

ZICKA, LH, DUKES JS (2011) Weed Biology and Climate Change. Iowa, USA: John Wiley \& Sons, Ltd., Publication. P. 235.

ZIMDAHL RL (2013) Fundamentals of Weed Science. Academic Press Elsevier. 
543 Table 1. Year of surveys of the 100 palm plantations, 9 cereal plots and 50 greenhouses

544 between 1990 and 2003. One presence-absence plant list was available per year, compiled

545 from three annual surveys: to match the seasonal planting and harvest schedule, surveys were

546 carried out starting in October of each year (x), and repeated in February and June of the

547 following year $(x+1)$, to give a total of three surveys per year. The data from each set of

548 three surveys were then taken together to fully characterize each October $\mathrm{x}$ to June $\mathrm{x}+1 \mathrm{crop}$

549 year (ITCMI and ITDAS, 2002).

550

\begin{tabular}{|c|c|c|c|}
\hline & $\begin{array}{c}\text { Cereal } \\
\text { plots }\end{array}$ & Greenhouses & $\begin{array}{c}\text { Palm } \\
\text { plantations }\end{array}$ \\
\hline $1990-91$ & $\times$ & $\times$ & $\times$ \\
\hline $1991-92$ & & $\times$ & \\
\hline $1992-93$ & & $\times$ & $\times$ \\
\hline $1993-94$ & $\times$ & $\times$ & $\times$ \\
\hline $1994-95$ & $\times$ & $\times$ & \\
\hline $1995-96$ & & $\times$ & \\
\hline $1996-97$ & & $\times$ & \\
\hline $1997-98$ & & $\times$ & $\times$ \\
\hline $1998-99$ & $\times$ & $\times$ & $\times$ \\
\hline $1999-00$ & $\times$ & $\times$ & $\times$ \\
\hline $2000-01$ & $\times$ & $\times$ & $\times$ \\
\hline $2001-02$ & $\times$ & $\times$ & $\times$ \\
\hline $2002-03$ & $\times$ & $\times$ & $\times$ \\
\hline
\end{tabular}

551

552

553

554

555

556

557

558

559 
560 Table 2. Results of the Mixed-effects Generalized Linear Models analysing differences in 561 numbers of weed species (species richness lines) or percentages of weed species (other lines)

562 / transect along time. Each crop type was analyzed separately. Two models were compared 563 for analysis: one with time included as an explanatory variable and one without. For these 564 analyses, only the data from 2003 to 2010 were used. If the model with time had a lower AIC 565 (Akaike Information Criterion), time was considered as having a significant effect (i.e. $\Delta$ AIC $566>2$; Burnham \& Anderson, 2004). The F and p-value correspond to the model with time 567 included as an explanatory variable.

\begin{tabular}{|l|c|c|c|c|c|}
\hline Variables & $\begin{array}{c}\text { AIC } \\
\text { model } \\
\text { with time }\end{array}$ & $\begin{array}{c}\text { AIC } \\
\text { model } \\
\text { without } \\
\text { time }\end{array}$ & df & F & p-value \\
\hline Species richness in cereal plots & $\mathbf{4 0 5 . 2}$ & 524.1 & 6 & 22.01 & $<0.001$ \\
\hline Species richness in greenhouses & $\mathbf{7 5 0 . 1}$ & 768.8 & 6 & 5.21 & $<0.001$ \\
\hline Species richness in palm plantations & 463.2 & $\mathbf{4 5 9 . 9}$ & 6 & 1.42 & 0.224 \\
\hline Therophytes in cereal plots & 412.48 & $\mathbf{4 1 1 . 0 5}$ & 6 & 1.75 & 0.127 \\
\hline Therophytes in greenhouses & $\mathbf{8 6 7 . 9 9}$ & 883.54 & 6 & 4.58 & $<0.001$ \\
\hline Therophytes in palm plantations & 461.4 & 460.83 & 6 & 1.93 & 0.092 \\
\hline Hemicryptophytes in palm plantations & 395.51 & $\mathbf{3 9 2 . 5 8}$ & 6 & 1.47 & 0.206 \\
\hline Complex chorotype in cereal plots & $\mathbf{3 9 6 . 8 6}$ & 404.21 & 6 & 3.24 & 0.008 \\
\hline Mediterranean in cereal plots & $\mathbf{3 7 2 . 1}$ & 393.2 & 6 & 5.63 & $<0.001$ \\
\hline Complex chorotype in greenhouses & $\mathbf{8 5 0 . 4}$ & 865.1 & 6 & 4.45 & $<0.001$ \\
\hline Alien in greenhouses & $\mathbf{8 7 1 . 3}$ & 970.2 & 6 & 16.59 & $<0.001$ \\
\hline Complex chorotype in palm plantations & 403.9 & $\mathbf{3 9 4 . 7}$ & 6 & 0.47 & 0.828 \\
\hline Saharo-Arabian chorotype in palm plantations & $\mathbf{4 2 4 . 5}$ & 438 & 6 & 4.13 & 0.002 \\
\hline
\end{tabular}


Figure legends are the same for the coloured online version and for the $B \& W$ version of

Fig. 1. Location of the study site in the region of Hassi Benabdellah, northeastern part of Saharan Algeria, about $800 \mathrm{~km}$ from Algiers (32 $\left.01^{\prime} \mathrm{N} ; 5^{\circ} 28^{\prime} \mathrm{E}\right)$.

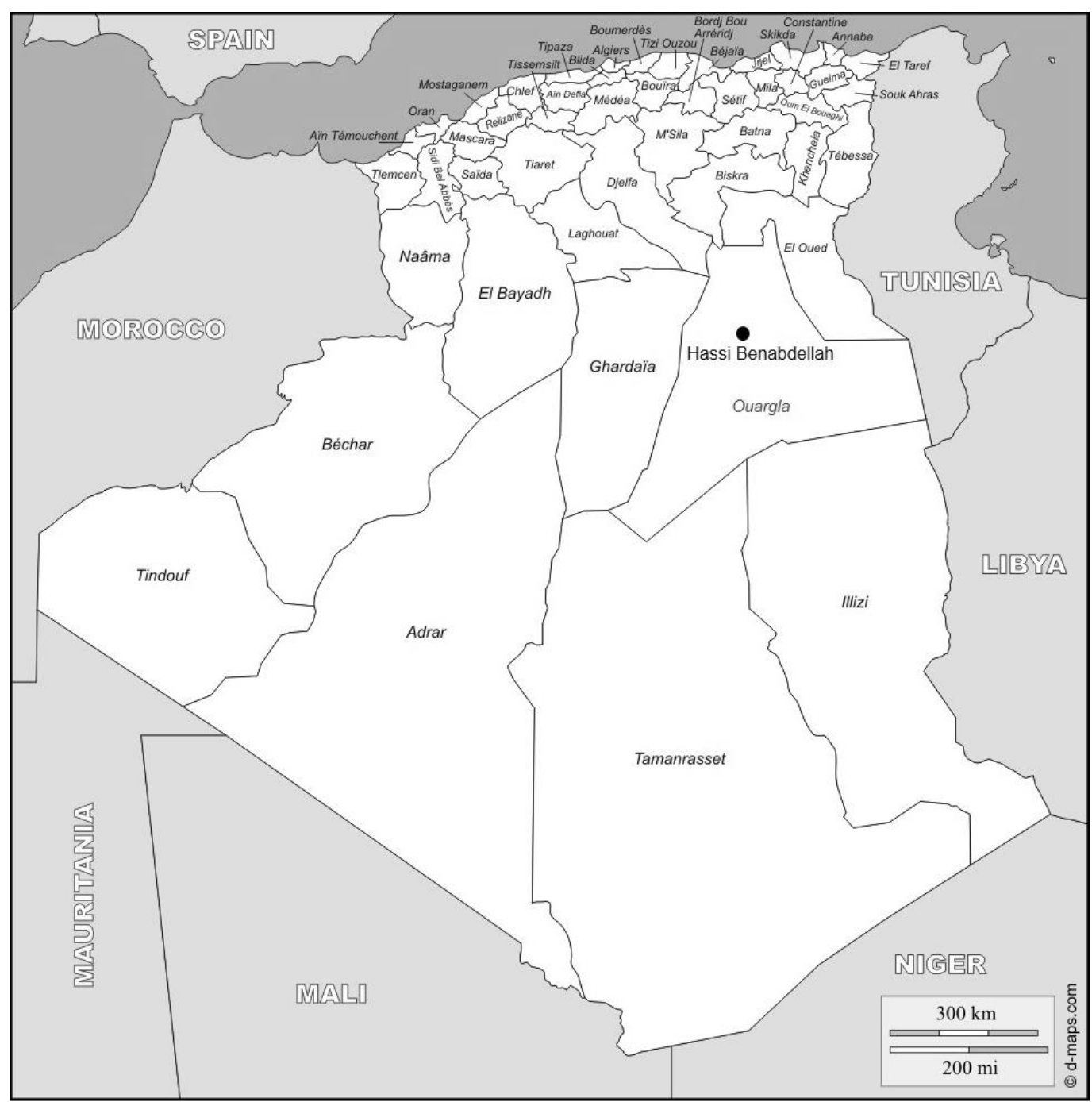


580 Fig. 2. Correspondence Analysis run on all data (282 samples $\times 162$ species). Only the most correlated species are shown. Samples are grouped according to the crop types.

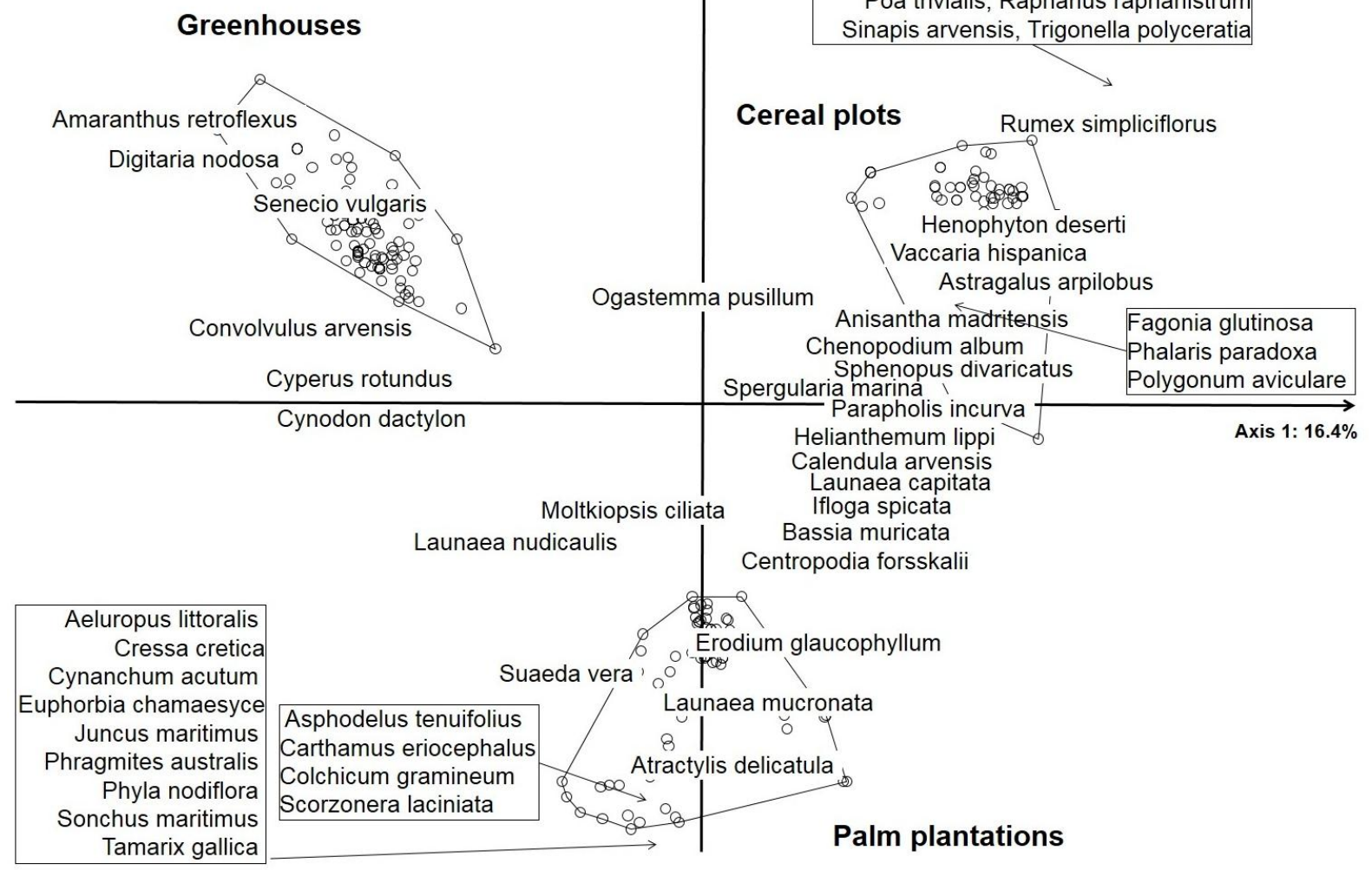


Fig. 3. Mean percentage of species / transect in each chorotype, considering crop types separately. For this analysis, only the data from 2003 to 2010 were used: cereal plots (sample unit $\left.=200 \mathrm{~m}^{2}\right)$, palm tree plantations ( sample unit $\left.=1000 \mathrm{~m}^{2}\right)$ and greenhouses $($ sample unit $=$ $50 \mathrm{~m}^{2}$ ). Values are shown as means \pm SE. Bars with common letters do not differ significantly according to Tukey's pairwise comparison tests ( $\mathrm{p}$-value $>0.05$ ).

591

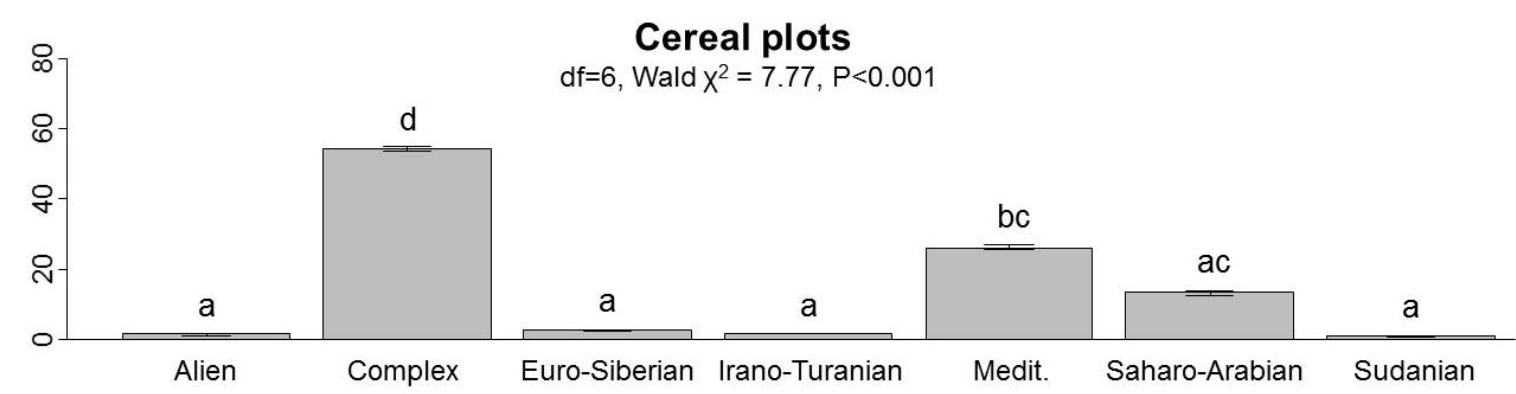

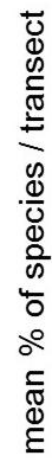
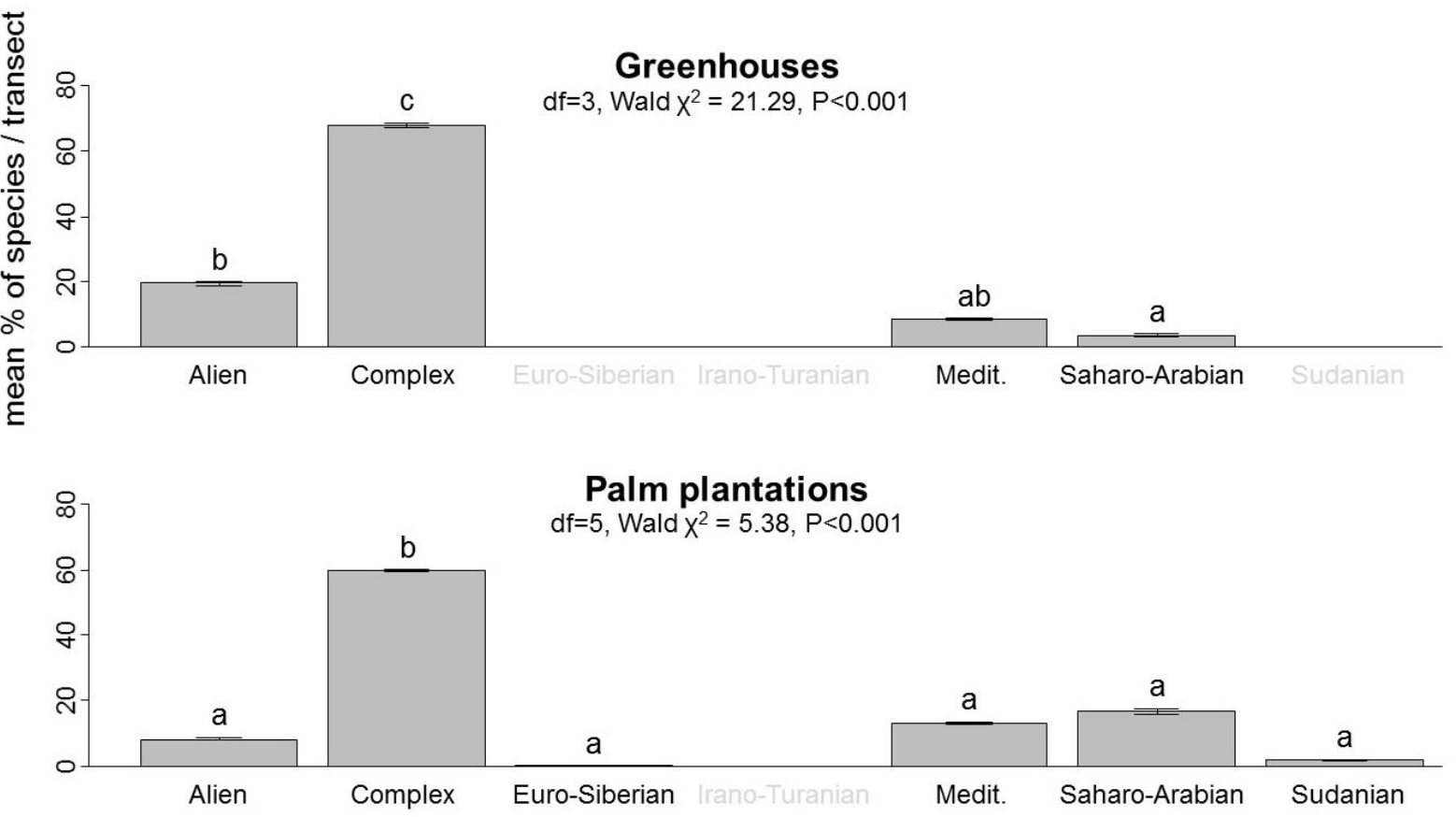
Fig. 4. Mean percentage of species / transect in each life form, considering crop types separately. For this analysis, only the data from 2003 to 2010 were used: cereal plots (sample unit $\left.=200 \mathrm{~m}^{2}\right)$, palm tree plantations $\left(\right.$ sample unit $\left.=1000 \mathrm{~m}^{2}\right)$ and greenhouses $($ sample unit $=$ $59850 \mathrm{~m}^{2}$ ). Values are shown as means \pm SE. Bars with common letters do not differ significantly 599 according to Tukey's pairwise comparison tests ( $\mathrm{p}$-value $>0.05$ ).

600

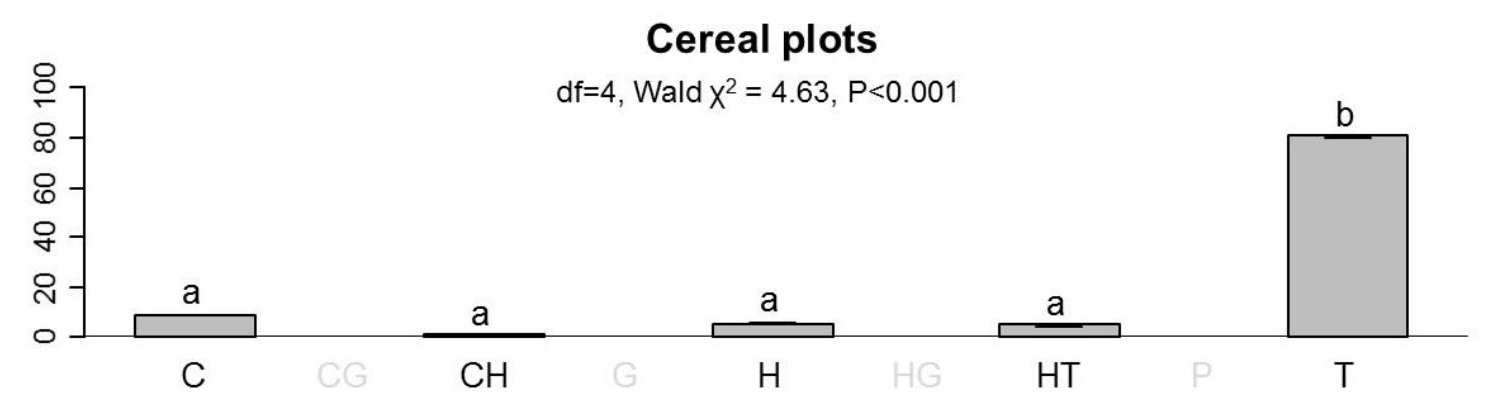

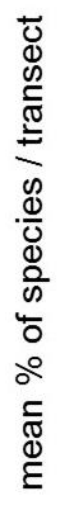

Greenhouses

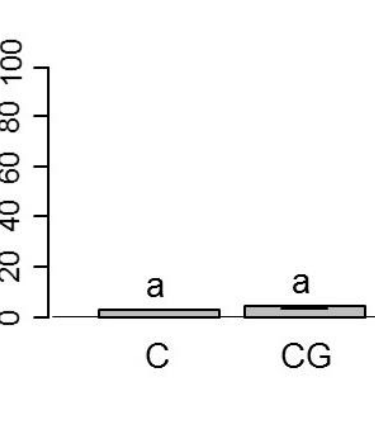

$d f=5$, Wald $X^{2}=28.66, P<0.001$

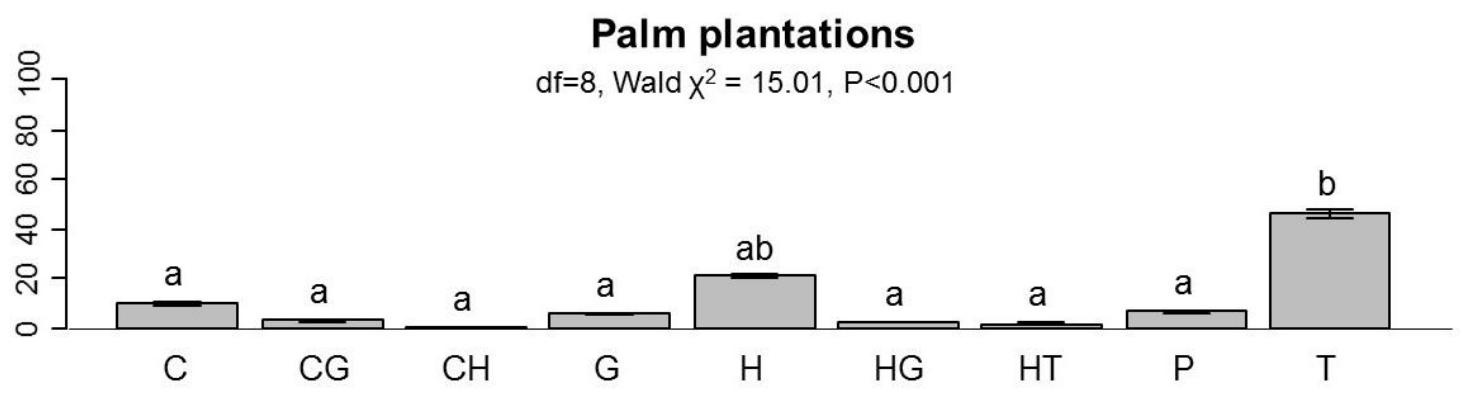

601

602

603 
604 Fig. 5. Mean number of weed species in each year from 1990 to 2010 considering crop types 605 separately: in the cereal plots (dot; sample unit $=200 \mathrm{~m}^{2}$ ), in the greenhouses (triangle; sample 606 unit $=50 \mathrm{~m}^{2}$ ) and in the palm plantations (cross; sample unit $=1000 \mathrm{~m}^{2}$ ). Analyses could only 607 be run on the data from 2003 to 2010. See results of analyses in Table 2. Values are shown as 608 means \pm SE. Points with common letters do not differ significantly according to Tukey's 609 pairwise comparison tests (p-value > 0.05).

610

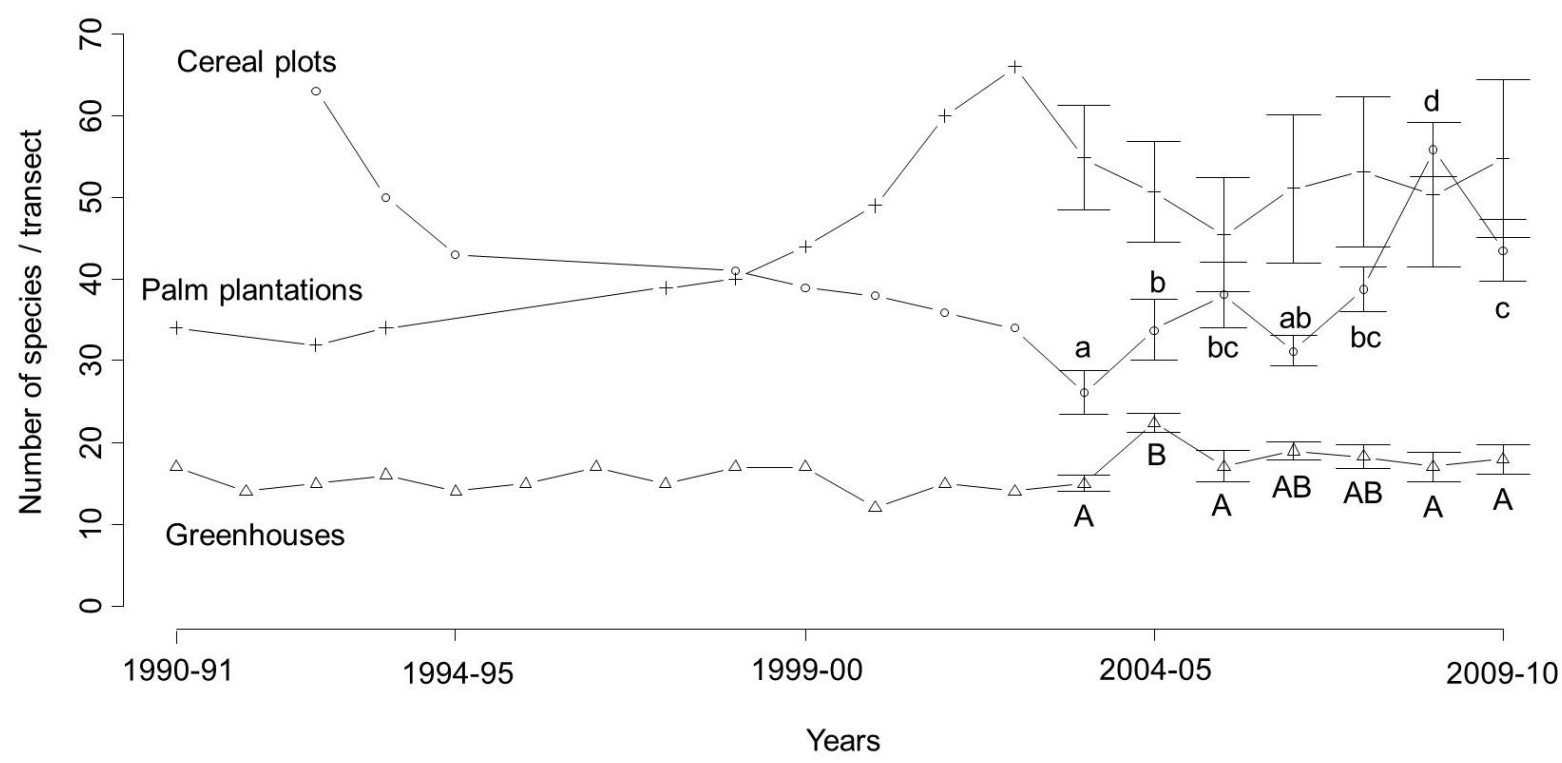

611

612

613 
614 Fig. 6. Percentage of species in a particular chorotype in each year from 1990 to 2010 ,

615 considering crop types separately: in the cereal plots (sample unit $=200 \mathrm{~m}^{2}$ ), in the 616 greenhouses (sample unit $=50 \mathrm{~m}^{2}$ ) and in the palm plantations $\left(\right.$ sample unit $=1000 \mathrm{~m}^{2}$ ). 617 Analyses were run on the data from 2003 to 2010, on the two most common chorotypes for

618 each crop type. See results of analyses in Table 2. Values are shown as means \pm SE. Points

619 with common letters do not differ significantly according to Tukey's pairwise comparison 620 tests (p-value >0.05).

621

\section{Cereal plots}
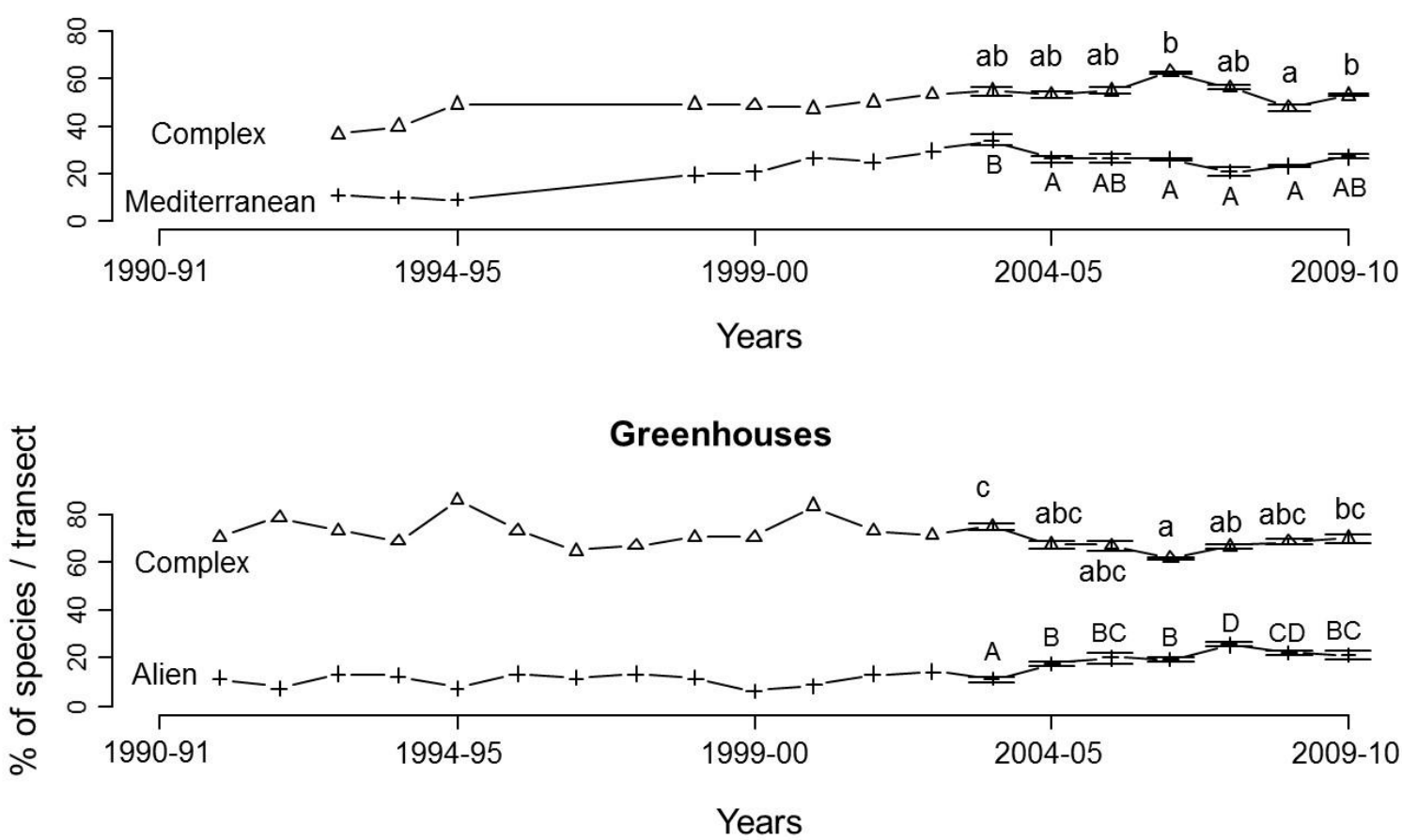

Palm plantations

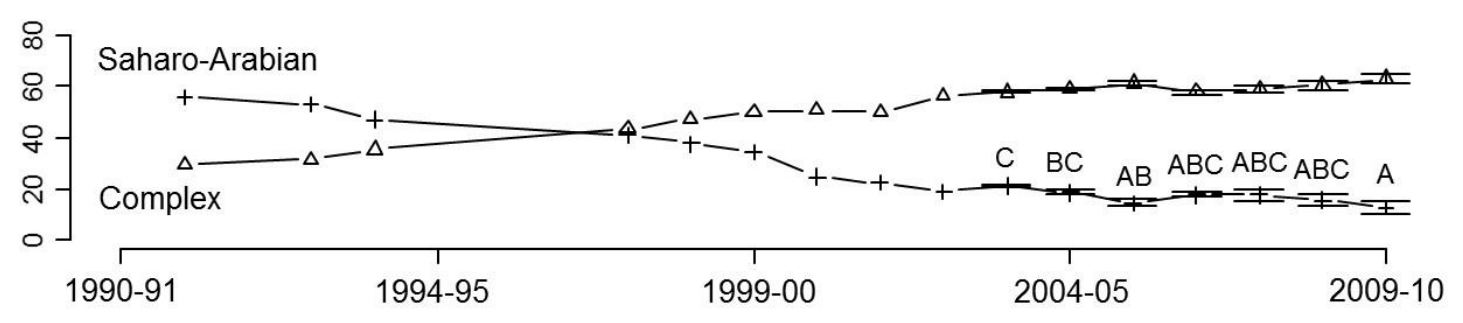


625 Fig. 7. Correspondence Analysis run on cereal plot data (71 samples $\times 104$ species). Only the 626 most correlated species are shown. Samples are grouped according to the year of study from 2003 to 2010. From 1990 to 2003, there is only one point (in grey) / year.

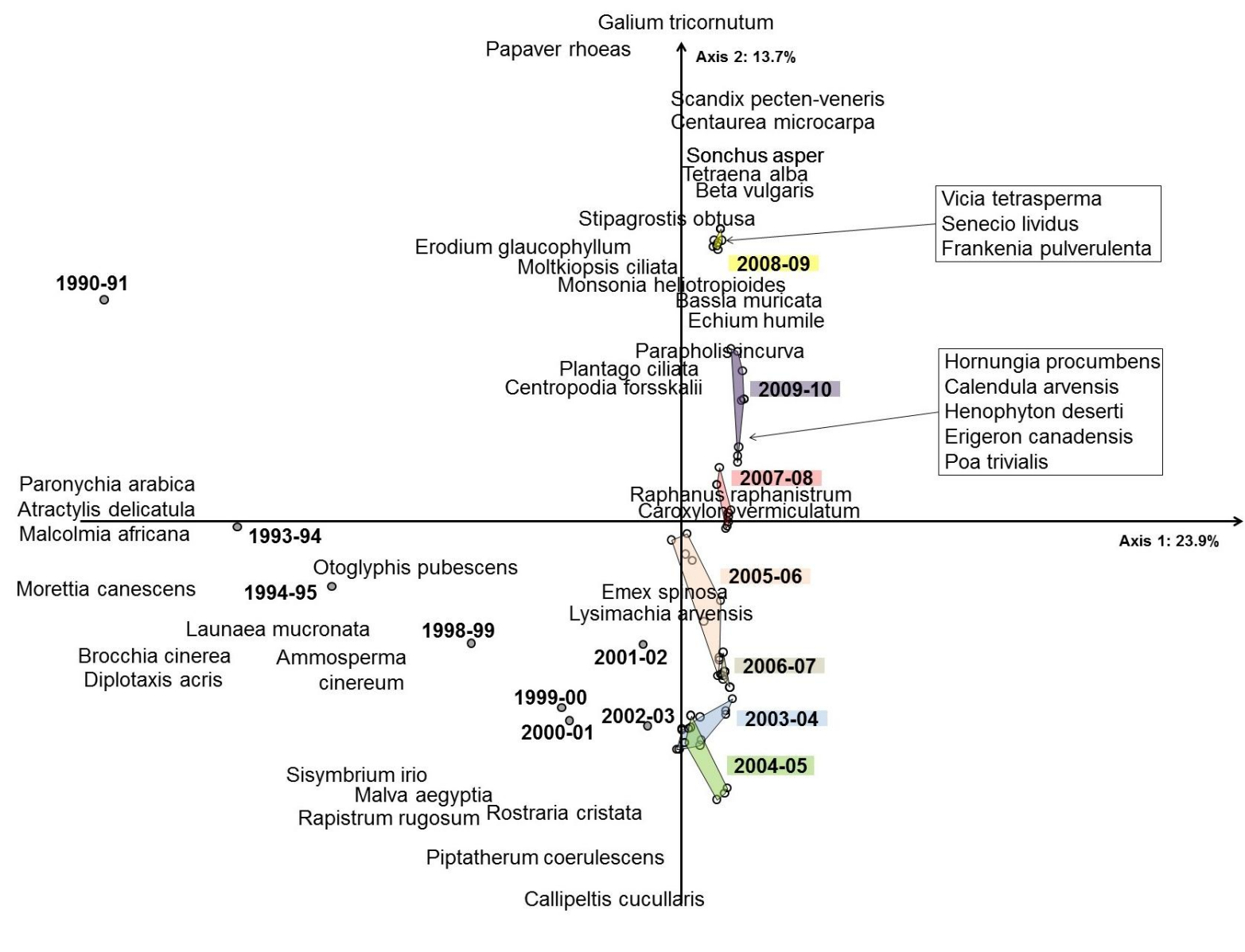


632 Fig. 8. Correspondence Analysis run on greenhouse data (139 samples $\times 31$ species). Only 633 the most correlated species are shown. Samples are grouped according to the year of study 634 from 2003 to 2010. From 1990 to 2003, there is only one point (in grey) / year.

635

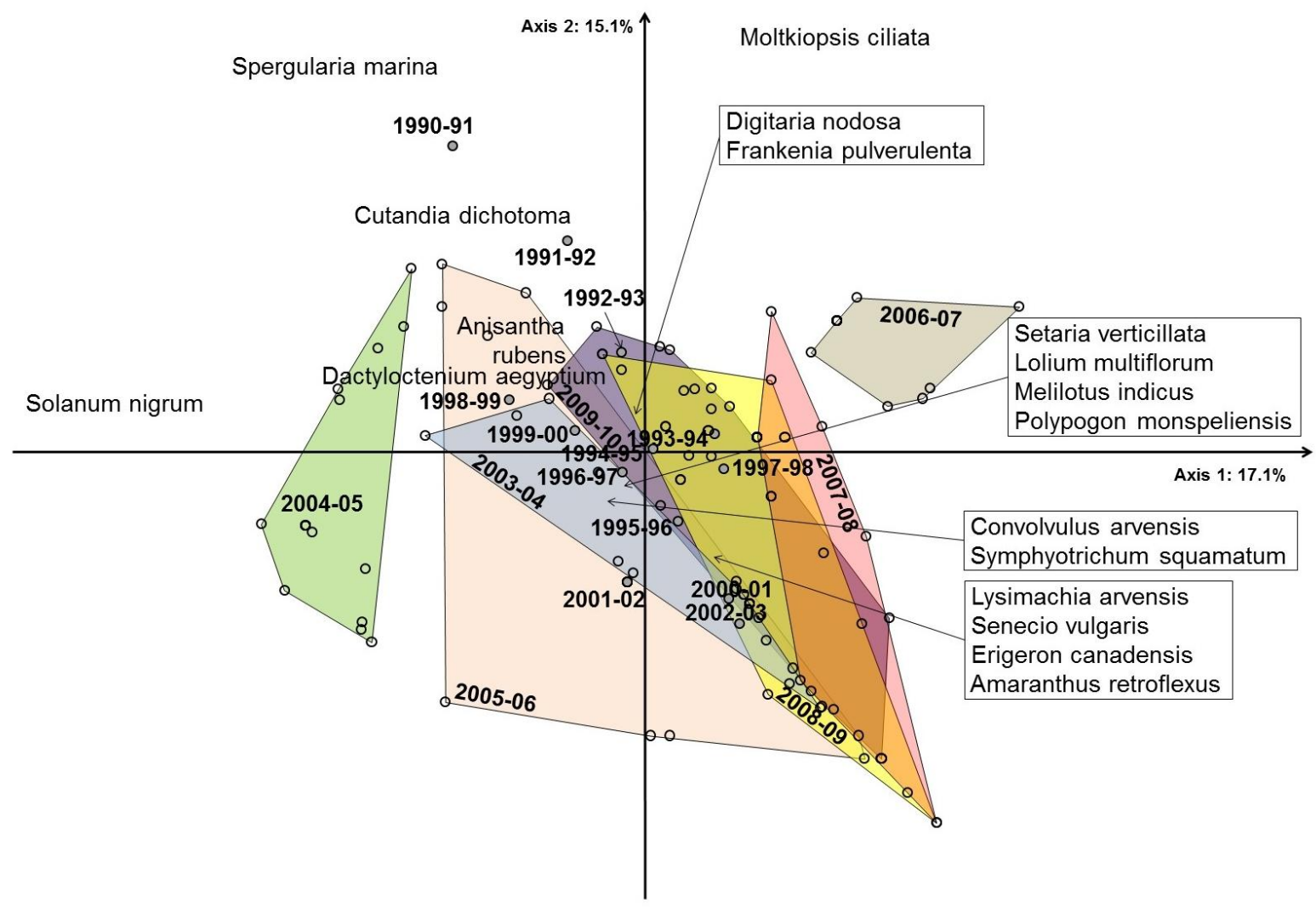


639 Fig. 9. Correspondence Analysis run on palm tree plantation data (72 samples $\times 119$ species). 640 Only the most correlated species are shown. Samples are grouped according to the year of 641 study from 2003 to 2010. From 1990 to 2003, there is only one point (in grey) / year.

642

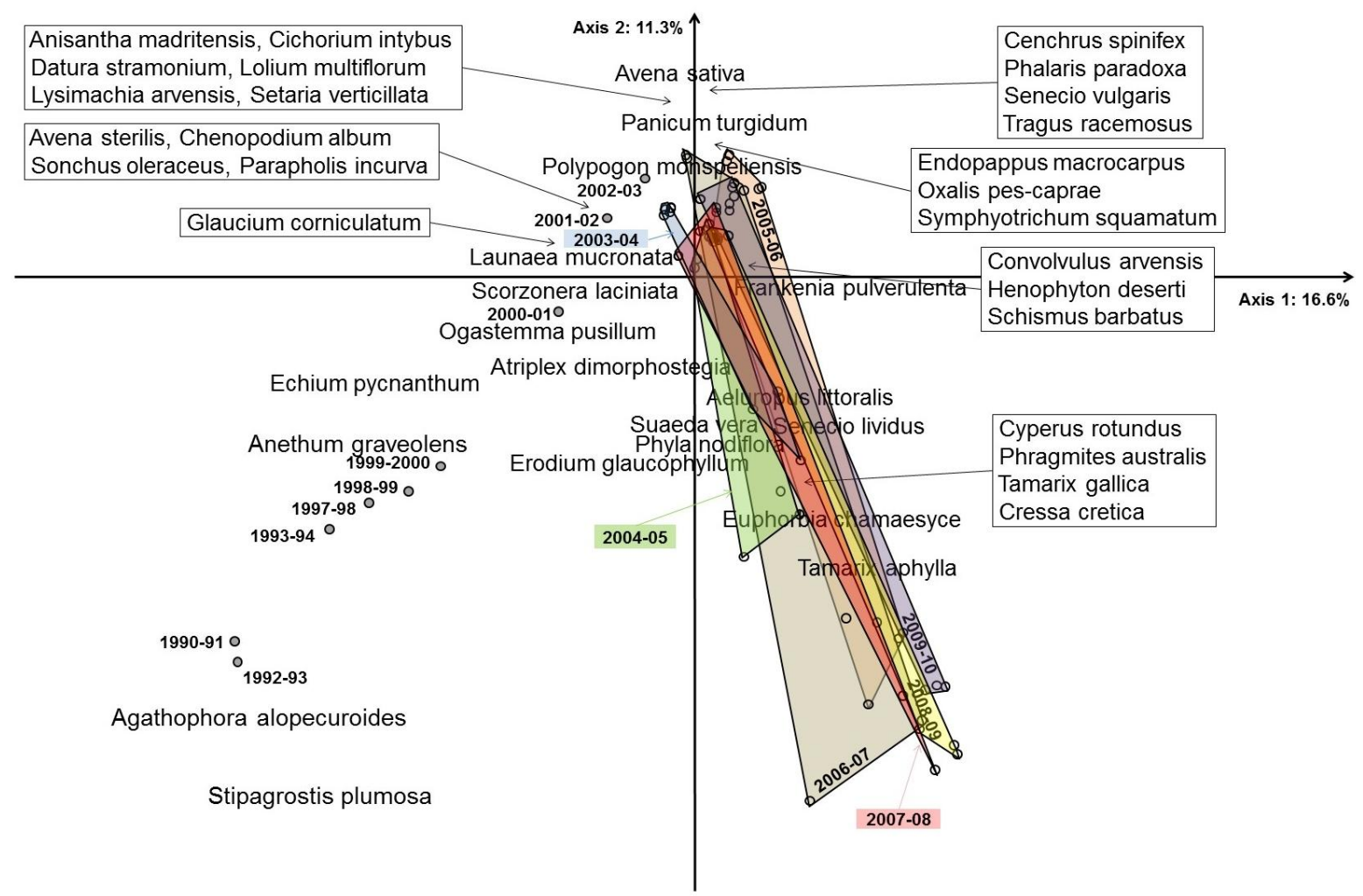

